Published July 2018

EKONOMIKAWAN : Jurnal Ilmu Ekonomi dan Studi Pembangunan

ISSN : 1693-7600 (Print), ISSN : 2598-0157 (Online), http://jurnal.umsu.ac.Id/index.php/ekawan

\title{
Analisis Pengaruh Belanja Sektor Kesehatan Terhadap Angka Harapan Hidup Di Sumatera Utara
}

\author{
Yuditya Nasution ${ }^{1}$ \\ Lailan Safina Hasibuan ${ }^{2}$ \\ Fakultas Ekonomi dan Bisnis Universitas Muhammadiyah Sumatera Utara \\ Jl. Kapten Muchtar Basri No. 3 Medan 20221 \\ e-mail :lailansafina@umsu.ac.id
}

\section{ABSTRAK}

Di dalam meningkatkan Pertumbuhan Perekonomian di suatu daerah sangat diperlukan peranan yang dominan Pemerintah di daerah tersebut, dimana pemerintah melakukan pembelanjaan dengan harapan semakin besarnya belanja pemerintah dapat semakin besar pertumbuhan ekonomi daerah tersebut. Indeks Pembangunan Manusia (IPM) yang didalamnya terdapat komponen angka harapan hidup merupakan salah satu alat ukur dalam melihat pertumbuhan ekonomi di suatu daerah. Apabila angka harapan hidup di suatu daerah semakin tinggi maka tingkat produktifitas masyarakat di daerah tersebut semakin tinggi pula diikuti dengan peningkatan pendapatan perkapita yang meningkatkan daya beli sehingga memacu pertumbuhan ekonomi daerah tersebut. Adapun tujuan dari penelitian ini adalah untuk meneliti pengaruh belanja kesehatan pemerintah dibidang kesehatan terhadap angka harapan hidup di provinsi sumatera utara. Data yang digunakan adalah data belanja pemerintah Sumatera Utara di bidang kesehatan dan data angka harapan hidup di Sumatera Utara dengan tahun dasar 2006-2014 yang diperoleh dari BPS Sumatera Utara dan Kementerian Kesehatan. Hasil dari Tipologi Klassen menunjukkan bahwa hubungan antara belanja sektor kesehatan dengan angka harapan hidup dalam kabupaten/kota provinsi Sumatera Utara bahwa daerah mana termasuk kategori pengeluaran perkapita tinggi dan mana daerah tingkat angka harapan hidup rendah.

Kata Kunci: Belanja Sektor Kesehatan, angka harapan hidup di Sumatera Utara. 
Published July 2018

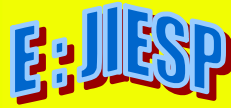

EKONOMIKAWAN : Jurnal Ilmu Ekonomi dan Studi Pembangunan

ISSN : 1693-7600 (Print), ISSN : 2598-0157 (Online), http://jurnal.umsu.ac.ld/index.php/ekawan

\title{
Analysis of the Effect of Health Sector Expenditures on \\ Life Expectancy in North Sumatra
}

\begin{abstract}
In increasing economic growth in an area, a dominant role is needed by the government in the area, where the government is spending in the hope that the greater the amount of government spending, the greater the economic growth of the region. The Human Development Index (HDI) in which there is a component of life expectancy is one of the measuring tools in looking at economic growth in an area. If the life expectancy in an area is higher then the level of productivity of the people in the area is also higher followed by an increase in income per capita which increases the purchasing power thus spurring the economic growth of the region. The purpose of this study was to examine the effect of government health spending in the health sector on life expectancy in the province of North Sumatra. The data used are North Sumatra government expenditure data in the field of health and life expectancy data in North Sumatra with the 2006-2014 base year obtained from the North Sumatra BPS and the Ministry of Health. The results of the Klassen Typology show that the relationship between health sector spending and life expectancy in the North Sumatra provincial district / city that which area is included in the high per capita expenditure category and where the area of life expectancy is low.
\end{abstract}

Keywords: Health Sector Expenditures, life expectancy in North Sumatra.

\section{PENDAHULUAN}

Konsep pembangunan ekonomi saat ini telah diterapkan dengan lebih luas dan mulai melibatkan banyak faktor, Di samping faktor yang bersifat ekonomi pembangunan juga perlu didukung dengan kemajuan dibidang non ekonomis atau yang bersifat sosial. Para ahli telah banyak mengkaji indikator-indikator sosial yang menjadi pendukung utama bagi pencapaian pembangunan bagi suatu bangsa. Indikator-indikator tersebut antara lain, tingkat pendidikan, kondisi dan kualitas pelayanan kesehatan, kecukupan kebutuhanperumahan, dan lain sebagainya. Dengan demikian, pembangunan ekonomi saat ini tidak hanya berorientasi ekonomi saja, melainkan telah berubah menuju arah pembangunan kualitas sumber daya manusia.

Mengingat pentingnya peran manusia dalam proses pembangunan ekonomi, maka peningkatan sumber daya manusia harus menjadi perhatian utama pemerintah. Peningkatan ini tidak hanya dilihat dari segi kuantitas saja melainkan jauh lebih penting dari segi kualitas.Pada dasarnya, setiap pemerintah didaerah berusaha untuk menentukan besaran belanja yang sesuai untuk menghasilkan iuran yang secara efektif dan efisien. 
Published July 2018

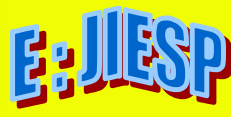

EKONOMIKAWAN : Jurnal Ilmu Ekonomi dan Studi Pembangunan

ISSN : 1693-7600 (Print), ISSN : 2598-0157 (Online), http://jurnal.umsu.ac.ld/index.php/ekawan

Perbedaan hasil studi tersebut menimbulkan sebuah dugaan bahwa mungkin masalah hubungan antara belanja kesehatan dengan capaian indikator kesehatan bukan hanya terletak pada sisi besaran belanja, melainkan juga pada sisi kualitas dan implementasi belanja pemerintah.

Menurut United Nation Development Program (UNDP), indeks pembangunan manusia (IPM) mengukur capaian pembangunan manusia berbasis sejumlah komponen dasar kualitas hidup. Sebagai ukuran kualitas hidup, IPM dibangun melalui pendekatan tiga dimensi dasar.Dimensi tersebut mencakup:

1. Umur panjang dan hidup sehat (a long and healthy life).

2. Pengetahuan (knowledge).

3. Standar hidup layak (decend standard of living).

Ketiga dimensi tersebut memiliki pengertian sangat luas karena terkait banyak faktor. Pada laporan pertamanya, UNDP mengukur dimensi kesehatan dengan menggunakan angka harapan hidup waktu lahir. Selanjutnya untuk mengukur dimensi pengetahuan digunakan angka melek huruf. Adapun untuk mengukur dimensi standar hidup layak digunakan indikator produk domestik bruto (PDB) per kapita.

Publikasi yang dilakukan oleh UNDP memperlihatkan bahwa secara absolut, IPM Indonesia telah mengalami peningkatan yang cukup berarti dalam beberapa tahun terakhir, namun masih jauh tertinggal dan beberapa negara khususnya ASEAN. HDI atau disebut dengan (Indeks Pembangunan Manusia) menjadi perbandingan internasional bagaimana pembangunan manusia suatu negara bisa diukur dalam suatu indeks. Misalnya seperti bagaimana kinerja pembangunan IPM Indonesia dibandingkan dengan negara-negara ASEAN yang lain.

Singapore menjadi Negara ASEAN dengan score IPM tertinggi yaitu 0,866 diikuti oleh Brunei Darussalam 0,838 dan Malaysia dengan 0,761. Dan Philiphines dengan score IPM mencapai 0,644. Indonesia berada diurutan ke-6 negara ASEAN dengan score IPM 0,617 dan disusul oleh negara Vietnam dengan 0,593 dan Laos dengan 0,524 dan Cambodia dengan IPM 0,523. Myanmar menjadi negara dengan tingkat IPM terendah di ASEAN dengan tingkat IPM 0,483.

Jika dibandingkan dengan provinsi lain di Pulau Sumatera, Sumatera Utara berada pada posisi keempat dari sepuluh provinsi. Di Sumatera, IPM tertinggi yaitu Kepulauan Riau, status pembangunan manusia provinsi pemekaran Riau tersebut telah masuk pada kategori "Tinggi". Provinsi Riau juga telah masuk pada kategori "Tinggi”. Sementara itu, Sumatera Barat, Sumatera Utara bersama dengan Aceh, Kep Bangka Belitung, Jambi, Bengkulu, Sumatera Selatan dan Lampung berada pada posisi "Sedang". Tidak ada provinsi di pulau Sumatera yang berada pada kategori pembangunan manusia "Sangat Tinggi" maupun "Rendah".

IPM Sumatera Utara tahun 2015 sebesar 69,51, lebih rendah dibanding Provinsi Kepulauan Riau, Riau dan Sumatera Barat. IPM terendah di Sumatera yaitu Provinsi Lampung dengan IPM sebesar 66,95. Walaupun di tingkat nasional IPM Sumatera Utara menduduki rangking ke 10, namun angka IPM Sumatera Utara sedikit masih dibawah angka nasional yang mencapai 69,55.

Dan di Indonesia umumnya terjadi peningkatan yang signifikan, masih terdapat disparitas wilayah. Hal ini ditunjukkan oleh adanya perbedaan angka kematian bayi (AKB) yang mencolok di antara provinsi-provinsi di Indonesia. 
Published July 2018

Fill

EKONOMIKAWAN : Jurnal Ilmu Ekonomi dan Studi Pembangunan

ISSN : 1693-7600 (Print), ISSN : 2598-0157 (Online), http://jurnal.umsu.ac.ld/index.php/ekawan

Perbedaan AKB yang mencolok di antara provinsi-provinsi di Indonesia. Contohnya, di Nusa Tenggara Timur (NTT) AKB-nya adalah 80, empat kali lebih tinggi dari AKB yang hanya 20.dan sedangkan di Sumatera Utara bagian AKB-nya masih berada seimbang dan di susul oleh AKB-nya di provinsi Sumatera Barat.

Dalam dimensi umur panjang dan hidup sehat diwakili oleh indikator angka harapan hidup (AHH) saat lahir. Angka harapan hidup Sumatera Utara tahun 2015 yaitu 68,29 tahun, masih dibawah angka nasional yang mencapai 70,78 tahun. AHH Sumatera Utara berada di urutan cukup rendah yaitu 24 secara nasional. Angka harapan hidup tertinggi di Pulau Sumatera yaitu Provinsi Riau yang mencapai 70,93 tahun. Tidak hanya masih di bawah angka nasional, AHH Sumatera Utara paling rendah jika dibandingkan provinsi lain di pulau Sumatera.

Angka kematian bayi (AKB) merupakan indikator yang lazim digunakan untuk menentukan derajat kesehatan masyarakat, baik pada tataran provinsi maupun nasional. Selain itu, program pembangunan kesehatan di Indonesia banyak menitikberatkan pada upaya penurunan AKB. Angka kematian bayi merujuk kepada jumlah bayi yang meninggal pada fase antara kelahiran hingga bayi belum mencapai umur 1 tahun per 1.000 kelahiran hidup. Dari 259.320 bayi lahir hidup terdapat 1.970 bayi meninggal sebelum usia 1 tahun. Berdasarkan angka ini, diperhitungkan angka kematian bayi (AKB) di Sumatera Utara hanya 7,6/1000 kelahiran hidup (KH) pada tahun 2012. Rendahnya angka ini mungkin disebabkan karena kasus-kasus yang terlaporkan adalah kasus kematian yang terjadi disarana pelayanan kesehatan, sedangkan kasus-kasus kematian yang terjadi di masyarakat belum seluruhnya terlaporkan. Hasil Sensus penduduk 2010 berdasarkan Kabupaten/Kota diketahui bahwa AKB terendah adalah Kota Medan sebesar 14,7/1.000 KH dan yang tertinggi adalah Kabupaten Mandailing Natal dengan AKB sebesar 45,7/1.000 KH.

Kesehatan memiliki peran yang sangat penting dalam menciptakan sumber daya manusia yang berkualitas. Kondisi kesehatan yang buruk, khususnya pada ibu dan anak akan menciptakan kualitas sumber daya manusia yang rendah. Anak-anak yang kurang sehat akan mengalami gangguan dalam proses pendidikan.Gangguan kesehatan dapat membuat proses pendidikan di bangku sekolah terhambat, sehingga kualitas pendidikan pun akan mengalami penurunan. Begitu pula dengan ketenagakerjaan, tenaga kerja yang tidak sehat tidak akan mampu bekerja secara optimal, sehingga produktivitas para tenaga kerja akan menjadi rendah.Kondisi-kondisi seperti ini kedepannya akan sangat berpeluang besar menghambat proses pembangunan ekonomi negara. Terkait dengan hal tersebut maka untuk mencapai pembangunan ekonomi yang mapan, harus didahulukan dengan perbaikan kualitas sumber daya manusia, terutama di bidang kesehatan. Derajat kesehatan dapat terus ditingkatkan dengan salah satunya adalah peningkatan pembangunan berbagai fasilitas dan sarana layanan kesehatan public yang dilakukan baik langsung maupun tidak langsung, dengan keberadaannya yang representatif, murah, dan aksesnya mudah untuk dimanfaatkan secara optimal (Profil Kesehatan Sumatera Utara,2012).

Persebaran puskesmas di kabupaten/kota sudah cukup merata. Setiap kecamatan di provinsi Sumatera Utara sudah memiliki paling sedikit 1 (satu) puskesmas. Bila dibandingkan dengan jumlah penduduk Sumatera Utara (13.215.401 jiwa), maka 1 puskesmas melayani 23.225 jiwa, bila dibandingkan dengan standar nasional (IS 2010), 1 (satu) puskesmas melayani 30.000 jiwa, berarti pemerintah Provinsi Sumatera Utara telah mampu menyediakan sarana kesehatan khususnya puskesmas mencapai standar nasional tersebut. 
Published July 2018

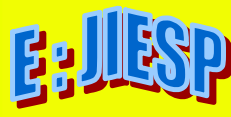

EKONOMIKAWAN : Jurnal Ilmu Ekonomi dan Studi Pembangunan

ISSN : 1693-7600 (Print), ISSN : 2598-0157 (Online), http://jurnal.umsu.ac.ld/index.php/ekawan

Merujuk profil kesehatan kabupaten/kota tahun 2012, jumlah kunjungan rawat jalan dan inap di seluruh puskesmas di Provinsi Sumatera Utara adalah 3.740.818 kunjungan. Bila diperkirakan rata-rata tiap penduduk memanfaatkan puskesmas adalah 1,5 kali, maka tahun 2012 diperkirakan persentase penduduk yang memanfaatkan puskesmas adalah 18,87\%, angka ini mengalami penurunan dibandingkan tahun 2011 yaitu 29,83\%.

Untuk lebih mendekatkan keterjangkauan masyarakat terhadap pelayanan kesehatan, dilaksanakan pelayanan kesehatan di puskesmas pembantu yang tersebar di wilayah kerja puskesmas induk. Pada tahun 2012, jumlah puskesmas pembantu di Provinsi Sumatera Utara sebanyak 2.085 unit. Bila dibandingkan dengan jumlah desa, maka ratio puskesmas pembantu dengan desa adalah sekitar 1:3. Sampai akhir tahun 2012 jumlah RS di Sumatera Utara adalah 200 unit dengan rincian, 58 unit RS Pemerintah dan 142 RS Swasta.

Untuk dapat mengukur seberapa besar keberhasilan program pembangunan kesehatan disuatu daerah dapat digunakan komponen dalam indeks pembangunan manusia yaitu angka harapan hidup. Dimana angka harapan hidup adalah angka harapan hidup pada suatu umur $\mathrm{x}$ adalah rata-rata tahun hidup yang masih akan dijalani oleh seseorang yang telah berhasil mencapai umur x. pada suatu tahun tertentu, dalam situasi mortalitas yang berlaku di lingkungan masyarakatnya atau angka harapan hidup saat lahir adalah rata-rata tahun hidup yang akan dijalani oleh bayi yang baru lahir pada suatu tahun tertentu.

Belanja kesehatan yang dikeluarkan pemerintah termasuk ke dalam alokasi belanja pembangunan. Belanja pembangunan merupakan pengeluaran yang bertujuan untuk pembiayaan proses perubahan dan bersifat menambah modal masyarakat baik dalam bentuk pembangunan fisik maupun non fisik. Mils dan Gilson (1990) memberikan kriteria belanja sektor kesehatan secara umum ke dalam lima aspek, yaitu; (1) pelayanan kesehatan dan jasa-jasa sanitasi lingkungan, (2) rumah sakit, institusi kesejahteraan sosial, (3) pendidikan, pelatihan, penelitian medis murni, (4) pekerjaan medis sosial, kerja sosial, (5) praktisi medis dan penyedia pelayanan kesehatan tradisional. Sektor-sektor tersebut yang kemudian akan mendapat alokasi belanja kesehatan dari pemerintah.

\section{METODE}

Penelitian ini dilakukan di Provinsi Sumatera Utara dengan melihat pada Kabupaten dan Kota yang di Provinsi Sumatera Utara. Data yang digunakan pada penelitian ini merupakan data sekunder yang dikumpulkan melalui study literatur terhadap publikasi instansi terkait BPS, Profil Kesehatan, Jurnal Ilmiah dan sumber lainnya yang berhubungan dengan masalah penelitian.

Untuk dapat menjawab tujuan penelitian, data yang telah dikumpulkan diolah dan kemudian dianalisis dan disajikan dalam bentuk diagram, grafik dan tabel. Metode yang digunakan untuk menganalisis perkembangan pengeluaran kesehatan serta tingkat harapan hidup di Kabupaten/Kota Provinsi Sumatera Utara digambarkan lewat scatter plot dengan menggunakan Tipologi Klassen.

Tipologi Klassen digunakan untuk memetakan Kabupaten dan Kota di Propinsi Sumatera Utara berdasarkan angka harapan hidup dan anggaran kesehatan. Dengan menentukan rata-rata angka harapan hidup sebagai sumbu vertikal dan anggaran kesehatan sebagai sumbu horizontal, daerah yang diamati dapat dibagi menjadi empat klasifikasi, yaitu:

1. Daerah dengan anggaran kesehatan dan angka harapan hidup yang tinggi (kuadran I) 
Published July 2018

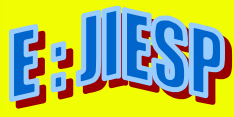

EKONOMIKAWAN : Jurnal Ilmu Ekonomi dan Studi Pembangunan

ISSN : 1693-7600 (Print), ISSN : 2598-0157 (Online), http://jurnal.umsu.ac.ld/index.php/ekawan

2. Daerah dengan anggaran kesehatan tinggi namun angka harapan hidupnya rendah (kuadran II)

3. Daerah dengan angka harapan hidup tinggi namun anggaran kesehatannya rendah (kuadran III)

4. Daerah relatif tertinggi, baik dalam anggaran kesehatan maupun angka harapan hidup (kuadran IV)

\section{PEMBAHASAN}

\section{Gambaran Umum Objek Penelitian}

\section{Kondisi Geografi Provinsi Sumatera Utara}

Provinsi Sumatera Utara berada dibagian barat Indonesia, terletak pada garis $1^{\circ}-4^{\circ}$ Lintang Utara dan $98^{\circ}-100^{\circ}$ Bujur Timur. Sebelah Utara perbatasan dengan Provinsi Nangroe Aceh Darussalam (NAD), sebelah Timur dengan Negara Malaysia diselat Malaka, sebelah Selatan berbatasan dengan Provinsi Riau dan Sumatera Barat dan disebelah Barat berbatasan dengan Samudera Hindia.

Berdasarkan kondisi letak dan kondisi alam, Sumatera Utara dibagi dalam 3 (tiga) kelompok wilayah yaitu Pantai Barat, Dataran Tinggi dan Pantai Timur. Provinsi Sumatera Utara tergolong ke dalam daerah berilklim tropis, Kisaran suhu antara $13,4^{\circ} \mathrm{C}-33,9^{\circ} \mathrm{C}$, mempunyai Musim Kemarau (Juni s/d September) dan musim hujan (November s/d Maret). Diantara kedua musim itu diselingi oleh musim pancaroba. Luas daratan Provinsi Sumatera Utara adalah 71.680,68 $\mathrm{Km}^{2}$ sebagian besar berada di daratan Pulau Sumatera dan sebagian kecil di Pulau Nias, Pulau-Pulau Batu, serta beberapa Pulau kecil baik dibagian Barat maupun bagian Timur pantai Pulau Sumatera.

Berdasarkan luas daerah menurut Kabupaten/Kota di Sumatera Utara, luas daerah terbesar adalah Kabupaten Mandailing Natal dengan luas 6.620,70 $\mathrm{Km}^{2}$ atau sekitar 9,23\% dari total luas Sumatera Utara. Diikuti Kabupaten-Kabupaten Langkat dengan luas $6.263,29 \mathrm{Km}^{2}(8,74 \%)$ kemudian Kabupaten Simalungun dengan luas 4.386,60 $\mathrm{Km}^{2}$ atau sekitar 6,12\%. Sedangkan luas daerah terkecil adalah Kota Sibolga dengan luas 10,77 Km² atau $0,02 \%$ dari total luas wilayah Sumatera Utara.

Berdasarkan kondisi letak ketinggian Kabupaten/Kota dari permukaan laut di Sumatera Utara mencapai ketinggian antara $0-2.220 \mathrm{M}$, letak ketinggian tertinggi adalah Kabupaten Samosir dan Toba Samosir yang mencapai 300-2.200 M, dan disusul oleh Kabupaten Labuhan Batu mencapai ketinggian 0-2.151 M. sementara Kabupaten Humbang Hasundutan mencapai ketinggian antara 330-2.075 M. sementara letak ketinggian terendah adalah Kota Gunung Sitoli mencapai 0 M, dan disusul oleh Kota Tanjung Balai mencapai 0-3 M dan Kota Binjai mencapai 0-28 M.

\section{Kependudukan}

Sumatera Utara merupakan Provinsi Keempat yang Terbesar jumlah penduduknya di Indonesia setelah Jawa Timur, Jawa Barat, dan Jawa Tengah. Berdasarkan Data dari BPS Provinsi Sumatera Utara, jumlah penduduk Sumatera Utara tahun 2014 tercatat sebesar 13.766,851 jiwa dengan tingkat kepadatan penduduk sebesar 192 per $\mathrm{Km}^{2}$. tingkat kepadatan penduduk yang tinggi didominasi oleh daerah perkotaan. 
Published July 2018

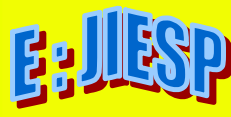

EKONOMIKAWAN : Jurnal Ilmu Ekonomi dan Studi Pembangunan

ISSN : 1693-7600 (Print), ISSN : 2598-0157 (Online), http://jurnal.umsu.ac.ld/index.php/ekawan

Kota yang memiliki kepadatan penduduk tertinggi adalah Kota Medan sebesar 8.265,33 jiwa per $\mathrm{Km}^{2}$, disusul dengan Kota Sibolga dengan kepadatan penduduk sebesar 8.000,56 jiwa per $\mathrm{Km}^{2}$ dan Kota Tebing Tinggi dengan kepadatan penduduk sebesar 4.027,16 jiwa per $\mathrm{Km}^{2}$. daerah dengan kepadatan penduduk terendah yaitu Kabupaten PakPak Barat sebesar 36,54 jiwa per $\mathrm{Km}^{2}$. disusul dengan Kabupaten Samosir sebesar 50,57 jiwa per $\mathrm{Km}^{2}$ dan disusul Kabupaten Tapanuli Selatan sebesar 62,75 jiwa per $\mathrm{Km}^{2}$.

Jumlah penduduk laki-laki di Sumatera Utara lebih sedikit dibandingkan dengan penduduk perempuan. Jumlah penduduk perempuan sebanyak 6.898,264 jiwa dan laki-laki $6.868,587$ jiwa, dengan sex ratio sebesar 99,57\%. Bila dilihat berdasarkan rata-rata banyaknya anggota keluarga di Sumatera Utara pada tahun 2014 adalah sebesar 4,27 (yang berarti rata-rata pada setiap keluarga terdiri dari 4-5 anggota keluarga). Kabupaten yang rata-rata jumlah anggota keluarganya paling banyak adalah Kabupaten Nias Barat yaitu 5,07 dan yang paling sedikit adalah Kabupaten Karo yaitu 3,70 orang.

Komposisi penduduk Sumatera Utara menurut kelompok umur, menunjukkan bahwa penduduk yang berusia muda (0-14 tahun) sebesar 32,22\% yang berusia produktif (15-64 tahun) sebesar 63,85\% dan yang berusia tua ( $>65$ tahun) sebesar 3,93\%. Dengan demikian maka angka beban tanggungan (Dependency Ratio) penduduk Sumatera Utara tahun 2014 sebesar $56,62 \%$. angka ini mengalami penurunan sebesar $0,16 \%$ bila dibandingkan dengan tahun 2013 sebesar 56,78\%.

Permasalahan kesehatan sangat dipengaruhi oleh tingkat sosial ekonomi masyarakat. Sejak terjadinya krisis moneter jumlah penduduk miskin meningkat secara drastis mencapai 30,77\% tahun 1998. Walaupun angka ini sudah dapat diturunkan secara signifikan sejak tahun 1999, namun data terakhir menunjukkan bahwa jumlah penduduk miskin tahun 2012 mengalami penurunan dari tahun 2011 yaitu 1.490,900 jiwa atau 10,8\% menjadi 1.378 .400 jiwa (10,4\%). Pada tahun 2014 jumlah penduduk miskin ini mengalami penurunan menjadi $1.360 .600(9,85 \%)$.

Jika dibandingkan dengan penduduk yang tinggal di kota dan desa, diketahui bahwa persentase penduduk miskin di daerah perkotaan lebih rendah dibandingkan dengan pedesaan yaitu $9,81 \%$ untuk perkotaan dan 9,89 untuk pedesaan.

\section{Pendidikan}

Pendidikan merupakan salah satu indikator yang kerap ditelaah dalam mengukur tingkat pembangunan manusia suatu negara. Pendidikan berkontribusi terhadap perubahan perilaku masyarakat. Pendidikan menjadi pelopor utama dalam rangka persiapan sumber daya manusia dan merupakan salah satu aspek pembangunan yang mutlak untuk mewujudkan tujuan pembangunan nasional. Untuk meningkatkan peran pendidikan dalam pembangunan, maka kualitas pendidikan harus ditingkatkan salah satunya dengan meningkatkan rata-rata lama sekolah. Pengetahuan yang dipengaruhi oleh tingkat pendidikan merupakan salah satu faktor pencetus predisposing yang berperan dalam mempengaruhi keputusan untuk berperilaku sehat.

Peningkatan kualitas dan partisipasi sekolah penduduk tentunya harus diimbangi dengan penyediaan sarana fisik pendidikan maupun tenaga guru yang memadai. Ditingkat pendidikan dasar, jumlah sekolah dasar (SD)/ Madrasah Ibtidiyah pada tahun 2013 ada sebanyak 9.432 unit dengan jumlah guru 122.128 orang, murid sebanyak 1.518.184 orang sehingga rasio murid SD terhadap sekolah sebesar $161 \mathrm{murid} / \mathrm{sekolah}$. 
Published July 2018

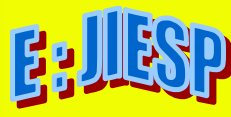

EKONOMIKAWAN : Jurnal Ilmu Ekonomi dan Studi Pembangunan

ISSN : 1693-7600 (Print), ISSN : 2598-0157 (Online), http://jurnal.umsu.ac.ld/index.php/ekawan

Jumlah Sekolah Lanjutan Tingkat Pertama (SLTP)/Madrasah Tsnawiyah ada sebanyak 2.357 sekolah dengan jumlah guru 57.563 orang dan jumlah murid ada sebanyak 552.761 orang, dan rasio murid SLTP terhadap sekolah sebesar 235 per sekolah. Pada tahun yang sama jumlah Sekolah Lanjutan Tingkat Atas (SLTA)/Madrasah Aliyah ada sebanyak 868 sekolah dengan jumlah guru 17.509 orang dan jumlah murid 233.916 dengan rasio murid terhadap sekolah sebesar 269 murid per sekolah. Jumlah Sekolah Menengah Kejuruan (SMK) ada sebanyak 828 unit dengan jumlah guru 14.178 orang dan jumlah murid 228.809 orang, dengan rasio murid terhadap sekolah sebesar 276 murid/sekolah. Sedangkan jumlah perguruan tinggi swasta pada tahun 2013 sebanyak 253 PTS , yang terdiri 31 Universitas, 86 Sekolah Tinggi, 4 Institut, 118 Akademi dan 14 Politeknik dengan jumlah dosen 6.340 orang (dosen tetap dan dosen tidak tetap) dengan jumlah mahasiswa sebanyak 244.947 orang. Dengan rasio mahasiswa terhadap dosen sebesar 38,58 .

Kemampuan membaca dan menulis tercermin dari Angka Melek Huruf yaitu penduduk usia 10 tahun keatas yang dapat membaca dan menulis huruf latin dan huruf lainnya. Pada tahun 2013, persentase penduduk Sumatera Utara yang melek huruf 97,84\% dimana persentase laki-laki lebih tinggi dari perempuan yaitu 98,31\% dan 95,93\%. Persentase penduduk berumur 10 tahun keatas yang melek huruf per Kabupaten/Kota tahun 2013 terendah di Kabupaten Nias Barat yaitu 84,48\% disusul Kabupaten Nias Selatan yaitu 85,38\% sedangkan yang tertinggi adalah Kabupaten Tapanuli Selatan sebesar $99,88 \%$.

Dana pengeluaran kesehatan Kabupaten/Kota Provinsi Sumatera Utara dilihat per tahun, ada 3 Daerah yang memiliki dana pengeluaran yang tinggi yaitu Kota Tebing Tinggi, Kota Medan dan Kota Binjai. Sementara dana pengeluaran yang terendah yaitu Kabupaten Padang Lawas, Kota Gunung Sitoli dan Kabupaten Simalungun.

dana pengeluaran kesehatan kabupaten/Kota Provinsi Sumatera Utara dilihat bahwa tahun 2006 dana yang dikeluarkan untuk kesehaatan yaitu Rp. 146.760.007 mengalami penurunan ditahun 2007 yaitu 153.458.200 yang mencapai 8,55\%. Pada tahun 2008 mencapai pengeluaran kesehatan yaitu Rp. 198.117.900 mengalami kenaikan dari tahun 2009 yaitu Rp. 194.915.308 yang mencapai 5,70\%. Dan tahun 2010 s/d tahun 2014 mengalami penurunan fluktuatif dalam dana pengeluaran kesehaan. Dari data diatas bahwa dana pengeluaran kesehatan Kabupaten/Kota dana yang tertinggi mencapai pada tahun 2011 yaitu Rp. 3.651.096.573 sedangkan dana yang terendah mencapai tahun 2006 yaitu Rp. 146.760.007. kenaikan dana kesehatan mengeluarkan dana kesehatan yang paling tinggi diraih oleh daerah Labuhan Batu $(19,67 \%)$. Sedangkan dana yang paling rendah diraih oleh daerah Humbang Hasundutan $(2,71 \%)$.

\section{Komposisi Cakupan Fasilitas Untuk Pelayanan Kesehatan di Kabupaten/Kota Sumatera Utara}

\section{Pelayanan Kesehatan Ibu dan Anak}

a. Pelayanan Antenatal Care (K4)

Pelayanan antenatal merupakan pelayanan kesehatan oleh tenaga kesehatan profesional (dokter spesialis obgyn, dokter umum, bidan dan perawat) seperti pengukuran berat badan dan tekanan darah, pemeriksaan tinggi fundus uteri, serta pemberian tablet besi kepada ibu hamil selama masa kehamilannya sesuai pedoman pelayanan antenatal yang ada dengan titik berat pada kegiatan promotif dan preventif. 
Published July 2018

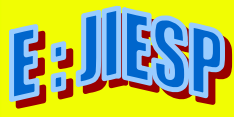

EKONOMIKAWAN : Jurnal Ilmu Ekonomi dan Studi Pembangunan

ISSN : 1693-7600 (Print), ISSN : 2598-0157 (Online), http://jurnal.umsu.ac.Id/index.php/ekawan

Cakupan K1 merupakan gambaran besaran ibu hamil yang telah melakukan kunjungan pertama ke fasilitas pelayanan kesehatan untuk mendapatkan pelayanan amtenatal. Sedangkan Cakupan K4 ibu hamil adalah gambaran besaran ibu hamil yang telah mendapatkan pelayanan ibu hamil sesuai dengan standar serta sedikit empat kali kunjungan dengan distribusi. Sekali pada triwulan pertama, triwulan kedua dan triwulan ketiga umur kehamilan. Angka ini dapat dimanfaatkan untuk melihat kualitas pelayanan kesehatan kepada ibu hamil. Kunjungan K4 ibu hamil di Sumatera Utara sejak tahun 2010 mengalami peningkatan yang melambat dari 3,31\% menjadi 85,85\% ditahun 2014 . Puncak peningkatan dalam 5 tahun ini terjadi pada tahun 2013 yaitu mencapai 88,7\%.

Merujuk pada target bidang kesehatan yaitu 95\% ditahun 2015 maka hanya tiga daerah yang telah mencapai K4 yaitu 95\% yaitu Kabupaten Deli Serdang (95,01\%), Kabupaten Batu Bara (97,72\%) dan Kota Medan (100,50\%). Tiga Kabupaten/Kota dengan cakupan terendah yaitu Kabupaten Nias Selatan (37,70\%), Kabupaten Padang Lawas $(50,97 \%)$ dan Kota Sibolga $(58,04 \%)$. Melihat pencapaian ini sangat diperlukan upaya-upaya yang lebih komprehensif serta berhasil guna untuk mengakselerasi cakupan K4 tersebut pada masa mendatang.

\section{b. Pelayanan Keluarga Berencana (KB)}

Keberhasilan program KB diukur dengan beberapa indikator, diantaranya proporsi peserta KB baru menurut metode kontrasepsi, persentase $\mathrm{KB}$ aktif terhadap jumlah pasangan usia subur (PUS) dan persentase baru metode kontrasepsi jangka panjang (MKJP).

Berdasarkan data dari BKKBN (Badan Koordinasi Keluarga Berencana Nasional) Provinsi Sumatera Utara, jumlah peserta KB baru adalah sebesar 419,961 atau 17,83\% dari PUS yang ada. Angka ini mengalami perlambatan dibandingkan tahun 2013 yaitu $20 \%$, tahun 2012 yaitu 19,44\%, lebih tinggi dibandingkan pencapaian tahun 2011 yaitu $14,08 \%$, tahun 2010 yaitu $17,05 \%$ dan tahun 2009 yaitu $14,58 \%$.

\section{c. Pelayanan Imunisasi}

Pencapaian UCI (Universal Child Immunization) merupakan proksi terhadap cangkupan atas imunisasi secara lengkap pada sekelompok bayi. Bila cangkupan UCI dikaitkan dengan batasan suatu wilayah tertentu, berarti dalam wilayah tersebut menggambarkan besarnya tingkat kekebalan masyarakat atau bayi terhadap penularan penyakit yang dapat dicegah dengan imunisasi. Dalam hal ini pemerintah mentargetkan pencapaian UCI pada wilayah administrasi Desa/Kelurahan. Suatu Desa/Kelurahan telah mencapai target UCI apabila $>80 \%$ bayi di Desa/Kelurahan tersebut sudah mendapat imunisasi lengkap.

Pencapaian desa dengan UCI di Provinsi Sumatera Utara tahun 2014 yaitu 71,4\% mengalami percepatan dibandingkan tahun 2013 yaitu 68,98\%. Namun mengalami perlambatan bila dibandingkan pencapaian tahun 2012 yaitu 74,19\%. Angka pencapaian tahun 2014 yaitu 71,4\% masih dibawah target nasional yaitu 100\% hanya 2 daerah yang $100 \%$ desanya telah mencapai UCI Kabupaten Simalungun dan Medan. 
Published July 2018

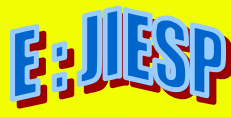

EKONOMIKAWAN : Jurnal Ilmu Ekonomi dan Studi Pembangunan

ISSN : 1693-7600 (Print), ISSN : 2598-0157 (Online), http://jurnal.umsu.ac.ld/index.php/ekawan

Pelayanan Kesehatan Jaminan Pemeliharaan Kesehatan Bagi Masyarakat Miskin (JPK MM/JAMKESMAS)

Sejak tahun 2008 program Askeskin berganti nama menjadi Jamkesmas (Jaminan Pemeliharaan Kesehatan Masyarakat). Program ini merupakan salah satu upaya pemerintah dalam bidang kesehatan untuk membantu masyarakat miskin mendapatkan pelayanan kesehatan secara gratis. Tujuan program ini adalah untuk meningkatkan aksesibilitas masyarakat miskin untuk mendapatkan pelayanan kesehatan.

Pada tahun 2014 jumlah penduduk miskin dengan jaminan pemeliharaan adalah 4.191.454 (30,45\%) mengalami peningkatan dibandingkan tahun 2013 yaitu 4.124.247 jiwa. Melebihi persentase penduduk miskin menurut data BPS yaitu 1.360.600 jiwa $(9,85 \%)$. Dapat disimpulkan bahwa program pemeliharaan kesehatan telah mencangkup bukan hanya masyarakat miskin tetapi juga masyarakat dalam kategori $a b u-a b u$ yaitu mereka yang jatuh miskin akibat sakit.

\section{Perkembangan Tingkat Harapan Hidup di Kabupaten/Kota Provinsi Sumatera Utara}

Berdasarkan survei BPS pencapaian tingkat angka harapan hidup di Kabupaten/Kota Provinsi Sumatera Utara mengalami perkembangan yang cukup pesat. Mengingat banyaknya peningkatan tingkat angka harapan hidup yang dikarenakan sejumlah penderita yang masih belum ditangani penyakit yang dideritanya tersebut. Tingkat angka harapan hidup yang tertinggi dan berkembang setiap tahunnya yaitu Pematang Siantar, Medan dan Binjai. Sedangkan tingkat angka harapan hidup terendah yaitu Mandailing Natal dan Tapanuli Selatan.

\section{Tipologi Klassen Kabupaten/Kota di Sumatera Utara berdasarkan pengeluaran anggaran kesehatan dan tingkat harapan hidup}

Tipologi Klassen digunakan untuk mengidentifikasi sektor, subsektor atau unggulan suatu daerah. Dalam hal ini Tipologi Klassen dilakukan untuk membagi daerah berdasarkan dua indikator utama, yaitu Anggaran Biaya Kesehatan dan Angka Harapan Hidup (AHH). Dengan menentukan rata-rata biaya kesehatan sebagai sumbu vertikal dan rata-rata Angka Harapan Hidup sebagai sumbu horizontal. Daerah yang diamati dapat dibagi menjadi empat klasifikasi, yaitu : daerah dengan biaya kesehatan dan angka harapan hidup yang tinggi (Kuadran 1), daerah dengan biaya kesehatan tinggi, namun angka harapan hidup rendah (Kuadran 11), daerah angka harapan hidup tinggi namun biaya kesehatan rendah (Kuadran 1ll), dan daerah relatif tertinggal, baik dalam biaya kesehatan maupun angka harapan hidup (Kuadran IV).

Dalam Tipologi Klassen tiap daerah akan diklasifikasikan daerah mana saja yang tergolong daerah dengan biaya kesehatan dan $\mathrm{AHH}$ yang tinggi, daerah yang hanya $\mathrm{AHH}-$ nya tinggi namun biaya kesehatan rendah. Dan daerah dengan biaya kesehatan tinggi,sementara AHH-nya rendah, serta $\mathrm{AHH}$ maupun biaya kesehatan kedua-duanya sama rendah.

Tiap daerah dapat diklasifikasikan kedalam 4 Kuadran seperti berikut ini : 


\section{גני EKONOMIKAWAN : Jurnal Ilmu Ekonomi dan Studi Pembangunan \\ ISSN : 1693-7600 (Print), ISSN : 2598-0157 (Online), http://jurnal.umsu.ac.Id/index.php/ekawan}

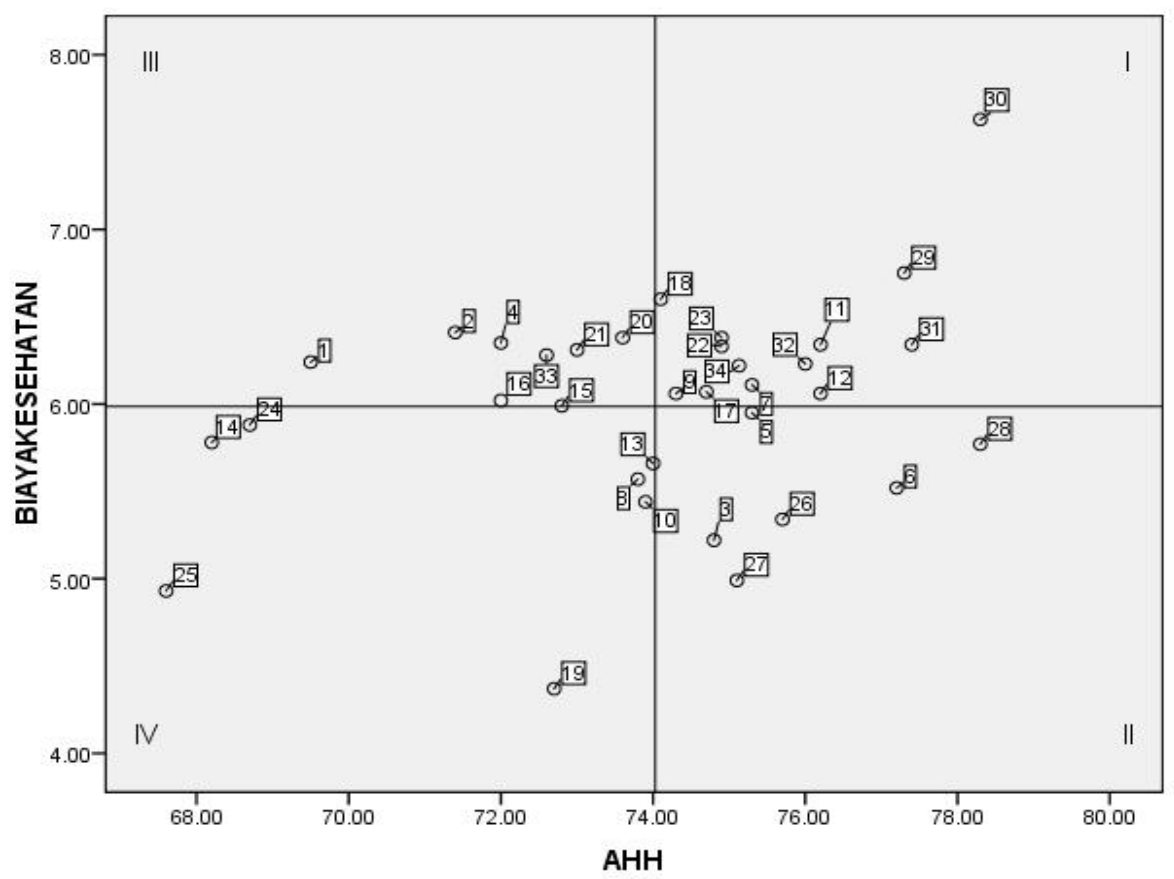

Gambar 4.3

Klasifikasi Tipologi Klassen

Keterangan :

1. Nias 15. Humbang Hasundutan

2. Mandailing Natal16. PakPak Barat

3. Tapanuli Selatan17. Samosir31. Binjai

4. Tapanuli Tengah18. Serdang Bedagai

5. Tapanuli Utara19. Batu Bara

6. Toba Samosir20. Padang Lawas Utara

7. Labuhan Batu21. Padang Lawas

8. Asahan 22. Labuhan Batu Selatan

9. Simalungun23. Labuhan Batu Utara

10. Dairi 24. Nias Utara

11. Karo 25. Nias Barat

12. Deli Serdang26. Sibolga

13. Langkat 27. Tanjung Balai

14. Nias Selatan28. Pemantang Siantar

Daerah yang terletak di Kuadran 1 yaitu : Kabupaten Karo, Tebing Tinggi,Kota Medan,Kota Binjai, dan Kota Padang Sidempuan termasuk dalam kategori daerah dengan biaya kesehatan dan angka harapan hidup yang tinggi, dikarenakan masing-masing Kabupaten/Kota baik nilai angka harapan hidup dan biaya kesehatannya diatas nilai ratarata, yaitu nilai rata-rata angka harapan hidup sebesar 74,00 dan nilai biaya kesehatan sebesar 6,00.
29. Tebing Tinggi

30. Medan

32. Padang Sidempuan

33. Gunung Sitoli 
Published July 2018

E⿹丁口

EKONOMIKAWAN : Jurnal Ilmu Ekonomi dan Studi Pembangunan

ISSN : 1693-7600 (Print), ISSN : 2598-0157 (Online), http://jurnal.umsu.ac.ld/index.php/ekawan

Daerah yang terletak di Kuadran II yaitu : Kabupaten Nias, Kabupaten Mandailing Natal, Kabupaten Tapanuli Tengah, Kabupaten Serdang Bedagai, Kabupaten Padang Lawas Utara, Kabupaten Padang Lawas, Kabupaten Labuhan Batu Selatan, Kabupaten Labuhan Batu Utara dan Kota Gunung Sitoli termasuk kedalam kategori Kuadran II yaitu daerah dengan biaya kesehatan tinggi namun angka harapan hidupnya rendah. Dikarenakan nilai masing-masing kabuupaten/kota memiliki nilai biaya kesehatan yang lebih rendah dan angka harapan hidup yang lebih tinggi dari nilai rata-rata, yaitu nilai ratarata $\mathrm{AHH}$ sebesar 74,00 dan nilai biaya kesehatan sebesar 6,00.

Daerah yang terletak di Kuadran III yaitu daerah Kabupaten Tapanuli Utara, Kabupaten Toba Samosir, Labuhan Batu Utara, Deli Serdang, Kota Sibolga dan Kota Pematang Siantar termasuk kedalam Kuadran III yaitu daerah dengan AHH tinggi namun biaya kesehatan rendah. Dikarenakan nilai masing-masing Kabupaten/Kota memiliki nilai AHH yang lebih tinggi dari nilai rata-rata, dan nilai biaya kesehatan yang lebih kecil dari nilai rata-ratanya yaitu nilai rata-rata $\mathrm{AHH}$ sebesar 74,00 dan nilai biaya kesehatan senilai 6,00 .

Daerah terletak Kuadran 1V yaitu : Tapanuli Selatan, Kabupaten Asahan, Kabupaten Simalungun, Kabupaten Dairi, Kabupaten Langkat, Nias Selatan, Kabupaten Humbang Hasundutan, PakPak Barat, Kabupaten Samosir, Kabupaten Batu Bara, Nias Utara, Kabupaten Nias Barat dan Tanjung Balai masuk dalam kategori Kuadran IV, yaitu daerah relatif tertinggal, baik dalam AHH maupun biaya kesehatan dikarenakan nilai masingmasing kabupaten/kota untuk nilai AHH maupun biaya kesehatannya dibawah nilai ratarata, yaitu nilai rata-rata yaitu nilai rata-rata $\mathrm{AHH}$ sebesar 74,00 dan biaya kesehatannya sebesar 6,00.

\section{SIMPULAN}

1. Pembiayaan kesehatan bersumber pemerintah, terutama APBD kabupaten/kota mengalami peningkatan setiap tahunnya, walaupun belum mencapai alokasi sebesar $10 \%$ untuk sektor kesehatan dari total APBD Kabupaten/Kota sesuai dengan tuntutan UU No. 36 Tahun 2009 tentang kesehatan.

2. Pelaksanaan Upaya kesehatan yang dilakukan di Provinsi Sumatera Utara dapat digambarkan sebagai berikut :
a. Cakupan K4 sebanyak $85,85 \%$
b. Cakupan Persalinan yang ditolong oleh tenaga kesehatan sebesar $87,28 \%$
c. Cakupan UCI sebesar $71,40 \%$

3. Dari analisis metode Tipologi Klassen untuk 33 Kabupaten/Kota Provinsi Sumatera Utara menunjukkan adanya 1 Kabupaten dan 4 Kota yang tergabung dalam kuadran 1 yaitu pertumbuhan ekonomi disertai pembangunan manusia yang tinggi, sementara untuk kuadran II terdapat 8 Kabupaten dan 1 Kota. Untuk kuadran III terdapat 4 Kabupaten dan 2 Kota. Sedangkan yang masuk kuadran IV terdapat 12 Kabupaten dan 1 Kota.

\section{SARAN}

1. Perlu peningkatan alokasi anggaran kesehatan terutama dari APBD Kabupaten/Kota guna mendukung pembangunan sektor kesehatan. 
Published July 2018

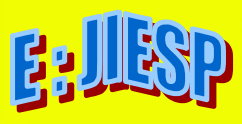

EKONOMIKAWAN : Jurnal Ilmu Ekonomi dan Studi Pembangunan

ISSN : 1693-7600 (Print), ISSN : 2598-0157 (Online), http://jurnal.umsu.ac.Id/index.php/ekawan

2. Meningkatkan sistem informasi kesehatan melalui peningkatan kemampuan tenaga kesehatan di dalam mengolah dan analisa data, khususnya teknis pengisian data kedalam tabel profil kesehatan.

3. Diharapkan adanya keseragaman dalam pengisian format tabel yang telah ditentukan serta ketepatan waktu dalam pengiriman profil kabupaten/kota sehingga memudahkan dalam penyusunan profil kesehatan provinsi ditahun mendatang.

4. Diharapkan profil kesehatan ini dapat mendukung kebutuhan data dan informasi di dalam penyusunan program kesehatan di provinsi sumatera utara dalam rangka mencapai sasaran target pembangunan kesehatan, baik di kabupaten/kota, provinsi dan pusat.

\section{DAFTAR PUSTAKA}

Anand Sudhir and Ravallion, Martin.1993.Human Development inPoorCountries: On the Role of Private Incomes and Public Services. The Journal of Economic Perspectives. Vol. 7. No. 1 (Winter,1993):133-150.

Badan Pusat statistik.2014. Indeks Pembangunan Manusia Provinsi dan Nasional 20042014, (Online), http://www.bps.go.iddiakses tanggal 15 januari 2018.

Badan Pusat statistik.2009. Indeks Pembangunan Manusia Provinsi dan Nasional 20062012,(Online),http://www.bps.go.iddiakses tanggal 15 januari 2018.

BPS-BAPPENAS-UNDP.2004. Indonesia Human Development Report 2004. Jakarta: BPS.

Darma, Budi.2011.Anggaran-Pendapatan-dan-Belanja-Daerah-APBD.

Diah Pradonowati. 2009. Efisiensi Sektor Unggulan Kecamatan di Kabupaten Klaten

Tahun 2000-2006. Skripsi Tidak Dipublikasikan, UniversitasDiponegoro.

Dinas Kesehatan Provinsi Sumatera Utara,2014, Profil Kesehatan Provinsi Sumatera Utara tahun 2014, Sumatera Utara.

Dinas Kesehatan Provinsi Sumatera Utara,2015, Profil Kesehatan Provinsi Sumatera Utara tahun 2015, Sumatera Utara.

Dinas Kesehatan Provinsi Sumatera Utara,2014, Profil Kesehatan Provinsi Sumatera Utara tahun 2014, Sumatera Utara.

Dinas Kesehatan Provinsi Sumatera Utara,2013, Profil Kesehatan Provinsi Sumatera Utara tahun 2013, Sumatera Utara.

Mangkoesoebroto, Guritno. 1999. Ekonomi Publik. Yogyakarta: BPFE.

Mardiasmo. 2004. Otonomi dan Manajemen Keuangan Daerah, Edisi Kedua,Yogyakarta: Penerbit Andi.

Mils. A. dan Gilson, L. 1990. Ekonomi Kesehatan untuk Negara Sedang Berkembang. Jakarta: Unit Analisa Kebijakan dan Ekonomi Kesehatan.

Peraturan Menteri Dalam Negeri No.54 Tahun 2010 tentang pelaksanaan peraturan pemerintah No 8 Tahun 2008.

Sujudi, Ahmad 2003. Investasi Kesehatan untuk Pembangunan Ekonomi. Jakarta : Departemen Kesehatan.

Sugiharti, Agung.2009. Pengaruh Anggaran Berbasis Kinerja terhadap Akuntabilitas

Dinas Pendidikan Kota Depok. Universitas Gunadharma.

Suparmoko.1996. Pengantar Ekonomi Makro. Yogyakarta: Penerbit UGM. 
Published July 2018

EKONOMIKAWAN : Jurnal Ilmu Ekonomi dan Studi Pembangunan

ISSN : 1693-7600 (Print), ISSN : 2598-0157 (Online), http://jurnal.umsu.ac.Id/index.php/ekawan

Suryanto, 2014. Pengelolaan Keuangan Daerah dan APBD. http://bpkad.natunakab.go.id/index.php/2018-01-21-00-44-45/64anggaran/87pengelolaan-keuangan-daerah-danpbd

Todaro, Michael P. 2003. Pembangunan Ekonomi Dunia Ketiga, Alih Bahasa : Burhanudin Abdullah dan Harris Munandar, Erlangga, Jakarta.

United nation Development Program, 2009, Human Development Report 2009. http://www.hdr.undp.org diakses tanggal 17 januari 2018.

Wasisto dan Ascobat.1986. Seminar Ekonomi Kesehatan. Jakarta : Departemen Kesehatan. 